\title{
METHOD DEVELOPMENT AND VALIDATION FOR SIMULTANEOUS ESTIMATION OF LEVOSULPIRIDE AND RABEPRAZOLE SODIUM: A NEW ANALYTICAL Q-ABSORBANCE RATIO APPROACH
}

\author{
BHARAT JHANWAR, BHUPENDRA SINGH*, GEETANJALI SAINI, SURAJPAL VERMA
}

Department of Quality Assurance, Lovely Institute of Technology, Lovely Professional University, Phagwara Jalandhar - 140 001, Punjab, India. Email: bhupendra.20773@lpu.co.in

Received 14 July 2017, Revised and Accepted 25 July 2017

\section{ABSTRACT}

Objective: The aim of the study was to develop a precise, accurate, and rapid ultraviolet spectrophotometric method for simultaneous estimation of levosulpiride (LEVO) and rabeprazole sodium (RBS) in the binary mixture and to validate the method as per ICH guidelines.

\begin{abstract}
Method: Estimation of LEVO and RBS was performed by Q-absorbance method. Analysis was performed using the ratio of absorbance at two selected wavelengths, one at iso-absorptive point and other is the absorbance maxima of any one of the components. Single scan spectrum and the overlain spectrum conclude that absorbance maxima of LEVO and RBS are 228 and $291.8 \mathrm{~nm}$, respectively, with a coinciding iso-absorptive point at $255 \mathrm{~nm}$. Method uses a ratio of absorbance for assay at 255 and the second wavelength is $291.8 \mathrm{~nm}, \lambda_{\max }$ for RBS. It is also applicable at $228 \mathrm{~nm}$, as the second wavelength.

Results: Linearity of LEVO and RBS was found to be $25-125$ and 4-36 $\mu \mathrm{g} / \mathrm{ml}$, respectively. The accuracy of the LEVO and RBS was found $99.26 \%$ and $99.51 \%$, respectively and Sandell's sensitivity ranged between 0.0238 and $0.594 \mu \mathrm{g} / \mathrm{cm}^{2}$. Assay of LEVO (75 mg) and RBS (20 mg) in capsule dosage form was found $99.5 \%$ and $98.69 \% \mathrm{w} / \mathrm{w}$, respectively.

Conclusions: The developed method for the estimation of LEVO and RBS in binary mixture were found to be simple, accurate, robust, and reproducible. No interference of excipients and the degraded product was found during the estimation. Therefore, the method can be successfully applied for
\end{abstract} routine quality control analysis.

Keywords: Levosulpiride, Rabeprazole sodium, Q-absorbance, ICH, Validation.

(C) 2017 The Authors. Published by Innovare Academic Sciences Pvt Ltd. This is an open access article under the CC BY license (http://creativecommons. org/licenses/by/4. 0/) DOI: http://dx.doi.org/10.22159/ajpcr.2017.v10s4.21331

\section{INTRODUCTION}

Levosulpiride (LEVO) is substituted benzamide antipsychotics. LEVO is an atypical antipsychotic agent that blocks the presynaptic dopaminergic D2 receptors. Like its parent compound, LEVO shows antagonism at $D_{3}$ and $\mathrm{D}_{2}$ receptors. LEVO is used in the treatment of the psychosis, anxiety disorder, premature ejaculation (not recommended in some countries), vertigo and irritable bowel syndrome. It is chemically known as-[[(2S)-1ethylpyrrolidin-2-yl] methyl]-2-methoxy-5-sulfamoyl benzamide (Fig. 1). It is soluble in methanol, ethanol, and DMSO.

Rabeprazole sodium (RBS) is a proton pump inhibitor. It is widely used as an antiulcer drug. It falls into the category of proton pump inhibitor. It is used in the treatment of gastric ulcer, peptic ulcer, ulcerative gastroesophageal reflux disease, duodenal ulcer Zollinger-Ellison syndrome, and Helicobacter pylori eradication in combination with amoxicillin. Chemically, it is 2-([4-(3-methoxypropoxy)-3-methylpyridin2-yl] methylsulfinyl)-1H-benzo[d]imidazole (Fig. 2). It is freely soluble in water; soluble in methanol, ethanol and ethyl acetate [1-3].

RBS can be estimated by liquid chromatography method which is official in Indian Pharmacopoeia (2007) [4]. There is no official method reported for the estimation in combination for both the selected drugs. There is some chromatographic method for estimation of single and both combination of rabeprazole and LEVO [5-7]. Some of the methods are available on combinations with itopride and mosapride but not with suggested drug combinations [8,9]. There is no method for selected combination has been developed by $\mathrm{Q}$ absorbance ratio. Hence, there is scope for the absorption ratio method is best suited for simultaneous estimation of RBS and LEVO in combined capsule dosage form by ultraviolet (UV) spectrometry. Q absorbance ratio method using UV-visible spectrophotometry depends on the property that for a substance, which obeys beer's law at all wavelength, the ratio of absorbance at any two wavelengths is a constant value independent of concentration or path length. The ratio of the two different wavelengths absorbance is known as $Q$ value $[10,11]$.

\section{METHODS}

Instruments

The spectrophotometric estimation was performed on Shimadzu UVvisible double beam spectrophotometer (Model-1800). Weighing of the chemicals was done on electronic analytical balance.

\section{Chemical and reagents}

The drug samples of LEVO and rabeprazole were obtained from Mankind Pharma, Baddi H.P. Marketed formulation, Rabekind Plus (Capsules) was procured from the market. All the other chemicals and reagents were of analytical grades.

Preparation of standard stock solution of LEVO $(1000 \mu \mathrm{g} / \mathrm{ml})$ Accurately weighed LEVO $100 \mathrm{mg}$ was dissolved in sodium hydroxide $(0.1 \mathrm{M})$ up to $100 \mathrm{ml}$ in a volumetric flask to produce $1000 \mu \mathrm{mg} / \mathrm{ml}$ of LEVO.

Preparation of standard stock solution of RBS $(100 \mu \mathrm{g} / \mathrm{ml})$

Accurately weighed RBS $25 \mathrm{mg}$ was dissolved sodium hydroxide (0.1 M) up to $25 \mathrm{ml}$ in a volumetric flask. Aliquots of $10 \mathrm{ml}$ of the stock solution were diluted up to $100 \mathrm{ml}$ from the same to produce $100 \mu \mathrm{mg} / \mathrm{ml}$ of RBS. 
Selection of wavelength

Aliquots of any one concentration of LEVO and RBS were scanned between 200 and $400 \mathrm{~nm}$ against $0.1 \mathrm{M}$ sodium hydroxide as blank. The absorbance maxima of LEVO and RBS were found to be 228 and $291.8 \mathrm{~nm}$, respectivelyv (Figs. 3 and 4). The overlain spectrum was obtained by combining both the scan. The isosbestic point was obtained at $255 \mathrm{~nm}$ (Fig. 5).

\section{IlPreparation of calibration curves}

Calibration curve of LEVO

Aliquots of LEVO in the concentration range of $25-125 \mu \mathrm{mg} / \mathrm{ml}$ were obtained by transferring $50 \mathrm{ml}$ of LEVO stock solution (1000 ppm) to the $100 \mathrm{ml}$ volumetric flasks and volume were made up of the solvent $0.1 \mathrm{M}$ sodium hydroxide. They were further diluted up to in series up to $10 \mathrm{ml}$ in volumetric using the same solvent. The absorbance of the solutions was measured at 255 (isobestic) and $291.8 \mathrm{~nm}$ (second $\lambda_{\max }$ ) against the solvent system as blank and calibration curves were plotted (Figs. 6 and 7).

\section{Calibration curve of RBS}

Aliquots of RBS in the concentration range of $4-36 \mu \mathrm{g} / \mathrm{ml}$ were obtained by transferring required volume of standard stock of RBS (100 ppm) to the series of $10 \mathrm{ml}$ volumetric flasks, and then volumes in each volumetric flask were made up with solvent $0.1 \mathrm{M}$ sodium hydroxide. The absorbance of the solutions was measured at 255 (isobestic) and $291.8 \mathrm{~nm}$ (self) against the solvent system as blank and calibration curves were plotted (Figs. 8 and 9).

\section{Preparation of synthetic mixtures of rabeprazole and LEVO}

The synthetic mixture of LEVO and RBS was prepared in a ratio of 15:4. They are accurately weighed $25 \mathrm{mg}$ and $6.6 \mathrm{mg}$, respectively, and were transferred to $25 \mathrm{ml}$ volumetric flask, and $15 \mathrm{ml}$ of the same solvent system was added. Common excipients, such as $8 \%$ starch, $7 \%$ magnesium stearate and $84 \%$ lactose, $1 \%$ talc, cellulose acetate phthalate (for $1000 \mu \mathrm{g} / \mathrm{ml}$ ) which were used in the formulation, were added to this mixture and sonicated for 20 minutes. Drug sample was prepared using basic knowledge of excipients available in text books [12]. This solution was filtered through the Whatman filter paper and residues were washed with the solvent system. The filtrate and washings were combined, and volume was made up to the $25 \mathrm{ml}$ with the solvent system. Then, $2.5 \mathrm{ml}$ of the solution was diluted to $10 \mathrm{ml}$ with the solvent system. The decision of this ratio of drugs in the synthetic mixture was based on the dosage strength of combination, which is available in the market. This combination has been approved by CDSCO, India, as capsule dosage form. It is marketed under the brand name "Rabekind," containing LEVO (75 mg) with rabeprazole $(20 \mathrm{mg})$.

Calibration curves of LEVO and rabeprazole in synthetic mixture The synthetic mixture $(1.2,1.8,2.4,3.0,3.6,4.2,4.8,5.4 \mathrm{ml})$ was transferred to a series of $10 \mathrm{ml}$ volumetric flasks separately, and volume was made up to the mark with the solvent system. The absorbance of these solutions was measured at 255 and $291.8 \mathrm{~nm}$ and calibration curves were plotted (Figs. 10 and 11).

\section{Introduction to Q-absorbance ratio method}

In absorption ratio method, the absorbance of both the drugs was calculated at two selected wavelengths among which $\lambda_{1}$ is the wavelength of isosbestic point (where both drugs show the same absorbance) and $\lambda_{2}$ is the $\lambda$ max of either drug among the drugs to be analyzed. From the overlain spectra, wavelength $255 \mathrm{~nm}\left(\lambda_{1}\right.$, i.e., an isosbestic point) and $291.8 \mathrm{~nm}\left(\lambda_{2}\right.$, i.e., absorbance maxima of rabeprazole) were selected for analysis. The concentration of the individual drug is determined by equations (1 and 2) written below [10,11].

$C_{x}=\frac{Q_{m}-Q_{y}}{Q_{x}-Q_{y}} \times \frac{A_{1}}{a_{x} 1}$

$\mathrm{C}_{\mathrm{x}}$ : Concentration of RBS.
$C_{y}=\frac{Q_{m}-Q_{x}}{Q_{y}-Q_{x}} \times \frac{A_{1}}{a_{y} 1}$

$\mathrm{C}_{\mathrm{y}}$ : Concentration of LEVO.

Where, $Q_{m}=\frac{A_{2}}{A_{1}}-A_{1}$ is absorbance of sample at $\lambda_{1}$ (isosbestic point),

$A_{2}$ is absorbance of sample at $\lambda_{2}\left(\lambda_{\max } R B S\right)$,

$\mathrm{Q}_{\mathrm{x}}=\frac{\mathrm{a}_{\mathrm{x} 2}}{\mathrm{a}_{\mathrm{x} 1}}-\mathrm{a}_{\mathrm{x} 1}, \mathrm{a}_{\mathrm{x} 2}$ : Absorptivities of RBS at $\lambda_{1}$ and $\lambda_{2}$ respectively,

$\mathrm{Q}_{\mathrm{y}}=\frac{\mathrm{a}_{\mathrm{y} 2}}{\mathrm{a}_{\mathrm{y} 1}}-\mathrm{a}_{\mathrm{y} 1}, \mathrm{a}_{\mathrm{y} 2}:$ Absorptivities of LEVO at $\lambda_{1}$ and $\lambda_{2}$, respectively.

The ratio of absorbance of calibration curves at different two wavelengths was calculated as below. These ratio values are used in equations to calculate the $Q_{m}$ values to determine the assay values. The values are given in Tables 1 and 2 .

\section{Calculation of $Q$ ratio equation values}

Absorptivities from the standard curve data are used to determine the absorptivities, as well as the ratio, are used for determination of $Q_{m}$ values. The calculation is given in Tables 3 and 4 .

Table 1: Ratio of absorbance of LEVO

\begin{tabular}{lllll}
\hline S.No. & Concentration (ppm) & \multicolumn{2}{l}{$\begin{array}{l}\text { Absorbance } \\
\text { in } \mathbf{~ n m}\end{array}$} & $\begin{array}{l}\text { Ratio of } \\
\text { absorbance }\end{array}$ \\
\cline { 3 - 4 } & & $\mathbf{2 5 5}$ & $\mathbf{2 9 1 . 8}$ & \\
\hline 1. & 25 & 0.291 & 0.188 & 1.547 \\
2. & 35 & 0.452 & 0.289 & 1.564 \\
3. & 45 & 0.489 & 0.310 & 1.577 \\
4. & 55 & 0.616 & 0.390 & 1.579 \\
5. & 65 & 0.743 & 0.465 & 1.598 \\
6. & 75 & 0.862 & 0.541 & 1.593 \\
7. & 85 & 0.938 & 0.590 & 1.589 \\
8. & 95 & 1.093 & 0.695 & 1.572 \\
9. & 105 & 1.303 & 0.822 & 1.585 \\
10. & 115 & 1.487 & 0.949 & 1.567 \\
11 & 125 & 1.539 & 0.979 & 1.571 \\
\hline
\end{tabular}

LEVO: Levosulpiride

Table 2: Ratio of absorbance of RBS

\begin{tabular}{lllll}
\hline S.No. & Concentration (ppm) & \multicolumn{2}{l}{$\begin{array}{l}\text { Absorbance } \\
\text { in } \mathbf{~} \mathbf{m}\end{array}$} & $\begin{array}{l}\text { Ratio of } \\
\text { absorbance }\end{array}$ \\
\cline { 3 - 4 } & & $\mathbf{2 5 5}$ & $\mathbf{2 9 1 . 8}$ & \\
\hline 1. & 4 & 0.021 & 0.096 & 0.218 \\
2. & 8 & 0.070 & 0.238 & 0.293 \\
3. & 12 & 0.111 & 0.392 & 0.285 \\
4. & 16 & 0.124 & 0.442 & 0.259 \\
5. & 20 & 0.189 & 0.667 & 0.283 \\
6. & 24 & 0.243 & 0.825 & 0.294 \\
7. & 28 & 0.290 & 0.935 & 0.305 \\
\hline
\end{tabular}

RBS: Rabeprazole sodium

Table 3: Value of absorptivities

\begin{tabular}{llll}
\hline $\mathbf{a}_{\mathbf{x} 1}$ & $\mathbf{a}_{\mathbf{x} 2}$ & $\mathbf{a}_{\mathbf{y} 1}$ & $\mathbf{a}_{\mathbf{y} 2}$ \\
\hline 12.896 & 41.887 & 9.776 & 6.252 \\
\hline
\end{tabular}

Table 4: Values of $Q$ ratio

\begin{tabular}{lll}
\hline $\mathbf{Q}_{\mathrm{x}}$ & $\mathbf{Q}_{\mathrm{y}}$ & $\mathbf{Q}_{\mathrm{m}}$ \\
\hline 3.24 & 0.639 & 1.295 \\
\hline
\end{tabular}




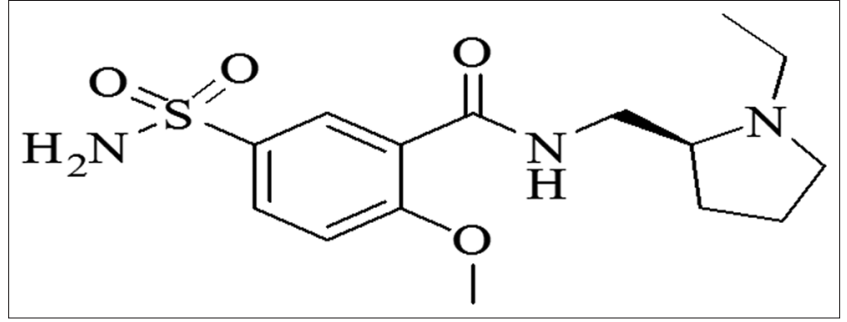

Fig. 1: Chemical structure of levosulpiride

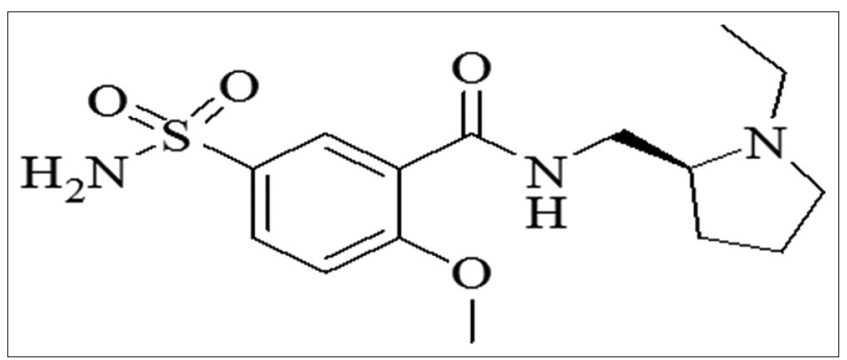

Fig. 2: Chemical structure of rabeprazole sodium

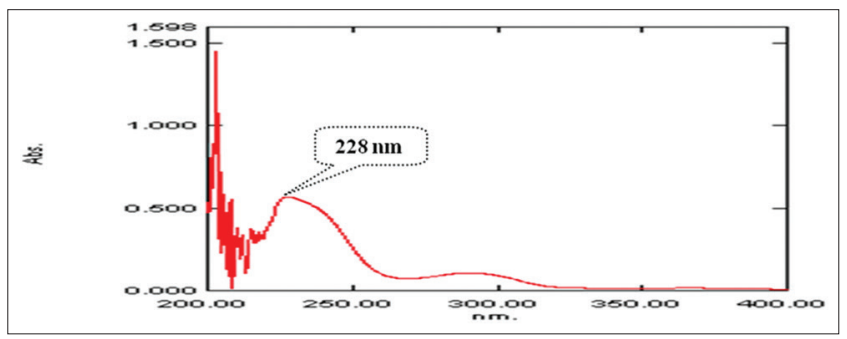

Fig. 3: Scan for determination of $l_{\text {max }}$ of levosulpiride

Validation of the developed method according to ICH guidelines

Following parameters were taken into consideration for validation of proposed methods [13-15].

1. Linearity: Linearity range is actually made of series of dilutions which are abiding the Beer Lambert's law. The intercept must be close to zero for the better linear following of dilution at selected wavelength. The result for linearity with respective $\mathrm{R}^{2}$ values and slope parameters for the active pharmaceutical ingredients (API) are given in Table 5.

2. Range:

a. Working range: It begins from limit of quantification to the maximum concentration used for the development of the analytical method. In this case, it is found to be $13.15-155 \mathrm{mg} / \mathrm{ml}$ and $3.17-36 \mathrm{mg} / \mathrm{ml}$ for LEVO and RBS, respectively.

b. Linearity range: It is the interval in which the response is directly proportional to the concentration between the upper and lower levels including the level (which is generally $\pm 5 \%$ of the intercept having a slope equal to zero). In this case, it is equal to $25-155 \mu \mathrm{g} / \mathrm{ml}$ and $4-36 \mu \mathrm{g} / \mathrm{ml}$ for LEVO and RBS respectively.

c. Target range: It is that concentration which is $80 \%, 100 \%$, and $120 \%$ of the target concentration. In this case, these are equal to $72.0,90.0$, and $108.0 \mu \mathrm{g} / \mathrm{ml}$ for LEVO and 16.0, 20.0, and $24.0 \mu \mathrm{g} / \mathrm{ml}$ for RBS.

d. Target concentration: It is defined as the concentration, which is equal to the midpoint of linearity range. It is equal $[(70+5) / 2]=37.5 \mathrm{mg} / \mathrm{ml}$. The results for range studies are shown in Table 6.

3. Accuracy: The results of analysis are obtained in three group containing three replicate experiments with API and capsule dosage

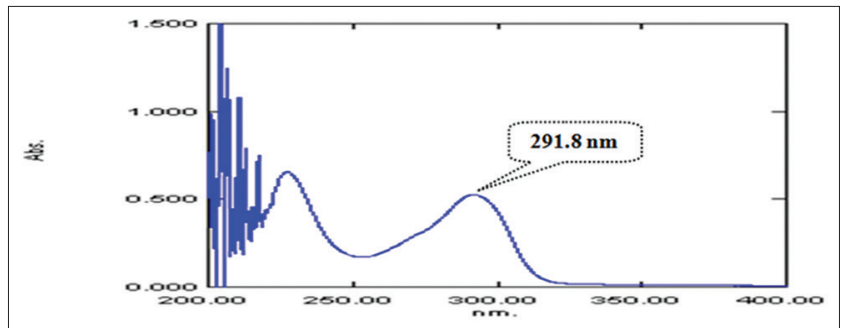

Fig. 4: Scan for determination of $\mathrm{l}_{\max }$ of rabeprazole sodium

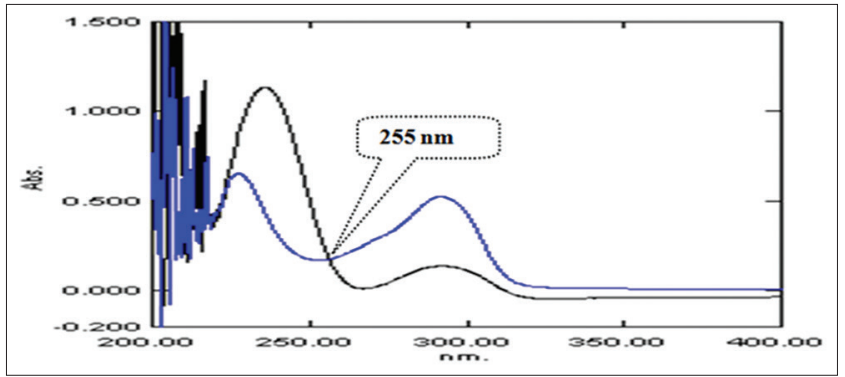

Fig. 5: Overlain spectra of levosulpiride and rabeprazole sodium

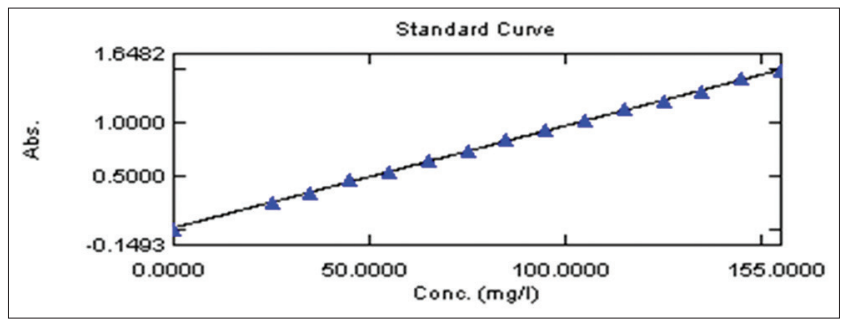

Fig.6: Calibration curve for levosulpiride at $255 \mathrm{~nm}$ (isobestic point)

form, had good agreement with the labeled amount of the drug.

a. Method: In nine different $10 \mathrm{ml}$ volumetric flasks, $1 \mathrm{ml}$ of the preanalyzed mixture solution $(100 \mu \mathrm{g} / \mathrm{ml})$ was taken and added $\mathrm{ml}$ of standard solution of bulk (API) mixture $(100 \mu \mathrm{g} / \mathrm{ml})$, and the volume was $0.12,0.16,1.9 \mathrm{ml}$ added up to $10 \mathrm{ml}$ with solvent system. The results are shown in Table 7.

4. Precision:

a. Repeatability: Repeatability was assessed using: Sixtime repetition of target concentration $100 \%$ that is $(20+90 \mu \mathrm{g} / \mathrm{ml} / 2=55 \mu \mathrm{g} / \mathrm{ml})$

b. Intra-day precision: In the study of the intraday which was conducted at three different times such as $9 \mathrm{am}, 12 \mathrm{pm}, 3 \mathrm{pm}$ on the solution having the concentration value $80 \%, 100 \%$ and $120 \%$ of the target concentration $(n=3)$

c. Interday precision: In the study of the interday which was conducted on the solution having concentration value $80 \%$, $100 \%$, and $120 \%$ of the target concentration $(n=3)$, on three different days. The results of precision are shown in Table 6 .

5. Limit of detection (LOD): The LOD was determined from the set of 6 calibration curves used to determine method linearity. The detection limit (LOD) may be expressed as: $\mathrm{LOD}=3.3(\mathrm{SD} / \mathrm{S})$

6. Limit of quantitation (LOQ): The LOQ was determined from the set of 6 calibration curves used to determine method linearity. The detection limit (LOQ) may be expressed as: $\mathrm{LOQ}=10(\mathrm{SD} / \mathrm{S})$

Where $\mathrm{SD}=$ Standard deviation of the response. It is actually the intercept of the calibration curve, $\mathrm{S}=$ Slope of the calibration curve. The results are shown in Table 6. 
Table 5: Optical and regression parameters

\begin{tabular}{|c|c|c|c|c|}
\hline \multirow[t]{2}{*}{ Parameters } & \multicolumn{2}{|l|}{ RBS } & \multicolumn{2}{|l|}{ LEVO } \\
\hline & $255 \mathrm{~nm}$ & $291.8 \mathrm{~nm}$ & $255 \mathrm{~nm}$ & $291.8 \mathrm{~nm}$ \\
\hline Beer's law limit $(\mu \mathrm{g} / \mathrm{ml})$ & 4-36 & & $25-155$ & \\
\hline Molar absorptivity $\left(\mathrm{L} \mathrm{mole}^{-1} \mathrm{~cm}^{-1}\right)$ & $4.916 \times 10^{3}$ & $1.597 \times 10^{4}$ & $5.747 \times 10^{3}$ & $4.25 \times 10^{3}$ \\
\hline Sandell's sensitivity ( $\mathrm{mg} / \mathrm{cm}^{2} / 0.001$ absorbance unit) & 0.0771 & 0.0238 & 0.0802 & 0.594 \\
\hline \multicolumn{5}{|l|}{ Regression equation } \\
\hline Slope (b) & 0.01231 & 0.04062 & 0.00960 & 0.00627 \\
\hline Intercept (a) & 0.00586 & 0.01509 & 0.01263 & 0.00037 \\
\hline Correlation coefficient & 0.99901 & 0.99900 & 0.99932 & 0.99940 \\
\hline
\end{tabular}

RBS: Rabeprazole sodium, LEVO: Levosulpiride

Table 6: Summary of validation parameters

\begin{tabular}{lll}
\hline Validation parameters & LEVO & RBS \\
\hline Specificity $(\%$ interference) & 0.209 & 0.145 \\
Linearity $(\mu \mathrm{g} / \mathrm{ml})$ & $25-155$ & $4-36$ \\
Range $(\mu \mathrm{g} / \mathrm{ml})$ & $13.15-155$ & $3.17-36$ \\
Precision** $(\% \mathrm{RSD})$ & & \\
$\quad$ Repeatability (n=6) & 0.91 & 0.825 \\
Intraday (n=3) & 0.255 & 0.177 \\
Interday (n=3 & 0.92 & 0.720 \\
Accuracy* (\% recovery) & 99.28 & 99.51 \\
LOD $(\mu \mathrm{g} / \mathrm{ml})^{*}$ & 4.34 & 1.2 \\
$\mathrm{LOQ}(\mu \mathrm{g} / \mathrm{ml})$ & 13.15 & 3.17 \\
\hline
\end{tabular}

*Acceptance criteria 99-101\%,**acceptance criteria: RSD $\leq 2$. LOD: Limit of detection, LOQ: Limit of quantitation, RSD: Relative standard deviation, RBS: Rabeprazole sodium, LEVO: Levosulpiride

7. Specificity:

a. Method: For specificity determination, a few excipients such as $8 \%$ starch, $7 \%$ magnesium stearate and $84 \%$ lactose, $1 \%$ talc, cellulose acetate phthalate (for $1000 \mu \mathrm{mg} / \mathrm{ml}$ ) were added, then after filtration, any change in absorbance are observed. The results are shown in Table 8 .

8. Assay procedure in capsule dosage form: 20 capsules were taken and the IP method was followed to determine the average weight.

a. Method: Above weighed capsule were finally weighed and contents were triturated well. Quantity of powder equivalent to $25 \mathrm{mg}$ of LEVO and $6.66 \mathrm{mg}$ of RBS (ratio is 15:4) was transferred to $25 \mathrm{ml}$ volumetric flask volume was made up to $25 \mathrm{ml}$ with previously sonicated solvent. The solution was filtered and the filtrate, $5 \mathrm{ml}$ was transferred to $25 \mathrm{ml}$ volumetric flask and volume was made up to $25 \mathrm{ml}$ with the solvent system. Then, 3.6, $4.5,5.4 \mathrm{ml}$ of aliquots were transferred to three $10 \mathrm{ml}$ volumetric flasks and volume were made up to $10 \mathrm{ml}$ with the same solvent. The absorbance was measured at $255 \mathrm{~nm}$ and $291.8 \mathrm{~nm}$. Percent capsule claim for LEVO and RBS was determined by abovediscussed equation 1 and 2 . The results are shown in Table 9.

\section{EXPERIMENTAL RESULTS}

Tables 5-9 summarizes the experimental results.

\section{DISCUSSIONS}

A UV spectrophotometry method was developed and validated for the determination of LEVO and rabeprazole in the binary mixture as per the ICH guidelines. The analytical method showed linearity in the concentration range of $25-155 \mu \mathrm{g} / \mathrm{ml}$ and $4-36 \mu \mathrm{g} / \mathrm{ml}$ for LEVO and RBS, respectively. The developed method showed good precision by $\%$ relative standard deviation of $0.255 \%$ and $0.177 \%$ for LEVO and RBS, respectively. Specificity of the developed analytical method was shown the negligible interference of the excipients. The \% interference was $0.209 \%$ and $0.145 \%$ for LEVO and RBS, respectively. The accuracy of the method was validated by mean percentage recovery which was found to be in the acceptable range of above $99 \%$ for both the drugs in combination.

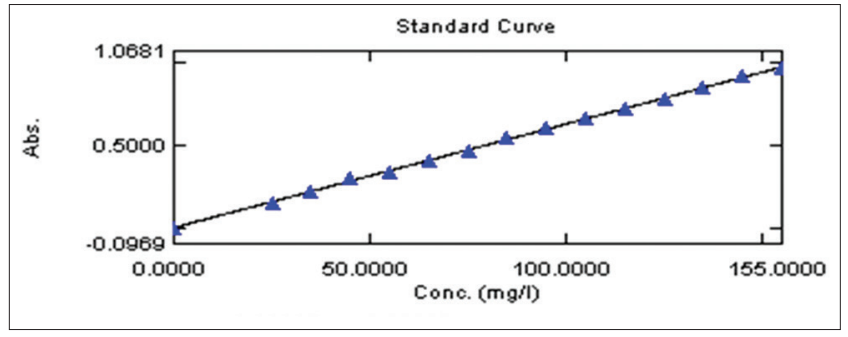

Fig. 7: Calibration curve for levosulpiride at $291.8 \mathrm{~nm}$ (second $\lambda_{\text {max }}$ )

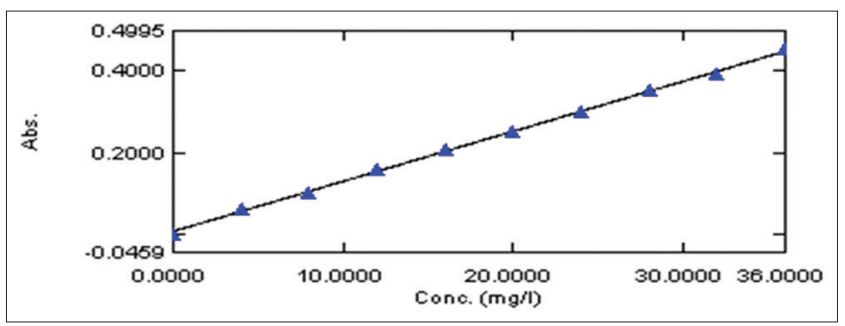

Fig. 8: Calibration curve for rabeprazole sodium at $255 \mathrm{~nm}$ (isobestic point)

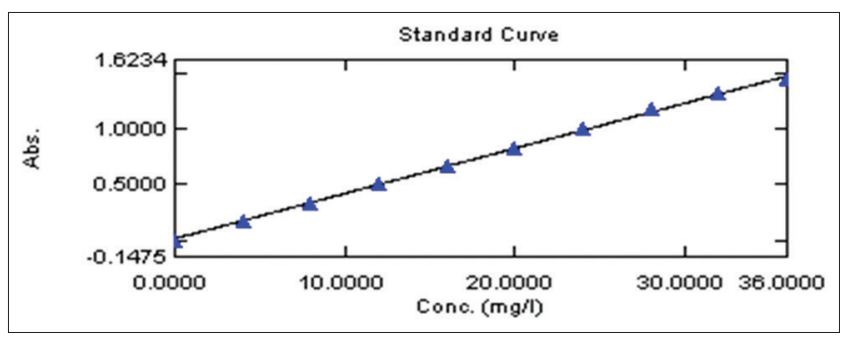

Fig. 9: Calibration curve for rabeprazole sodium at $291.8 \mathrm{~nm}$ (second $\lambda_{\text {max }}$ )

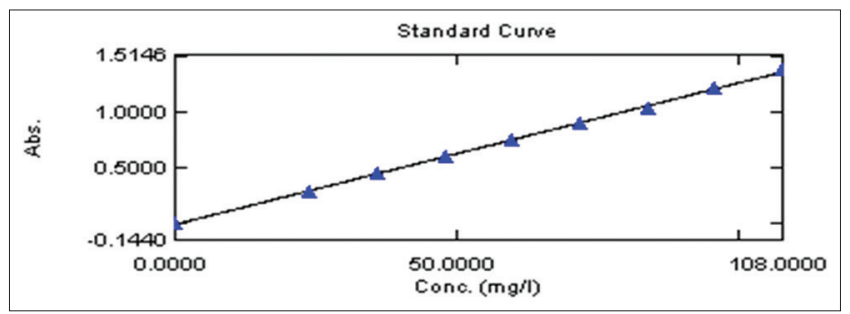

Fig. 10: Calibration curve for synthetic mixture at $255 \mathrm{~nm}$

\section{CONCLUSIONS}

The proposed method was linear, accurate, precise, and specific as per validation parameters (Table 9) discussed above as per ICH guidelines. 
Table 7: Recovery study (accuracy) in synthetic mixture

\begin{tabular}{|c|c|c|c|c|c|c|c|c|}
\hline S.No. & WL (nm) & $\begin{array}{l}\text { Concentration of } \\
\text { solution (ppm) }\end{array}$ & $\begin{array}{l}\text { Standard } \\
\text { added (ppm) }\end{array}$ & Absorbance & $\begin{array}{l}\text { Amount } \\
\text { found (mg) }\end{array}$ & \% Recovery & Mean recovery $\pm S D$ & $\%$ RSD \\
\hline \multirow[t]{2}{*}{$1^{*}$} & 255 & 90 & 4.86 & 1.18 & 94.2 & 99.36 & LEVO & \\
\hline & 291.8 & 24 & 1.28 & 1.59 & 25.1 & 99.41 & $99.28 \pm 0.1497$ & 0.99 \\
\hline \multirow[t]{2}{*}{$2^{*}$} & 255 & 90 & 4.86 & 1.17 & 94.1 & 99.58 & & \\
\hline & 291.8 & 24 & 1.28 & 1.58 & 25.0 & 99.33 & & \\
\hline \multirow[t]{2}{*}{$3 *$} & 255 & 90 & 4.86 & 1.19 & 94.3 & 99.6 & RBS & \\
\hline & 291.8 & 24 & 1.28 & 1.59 & 24.9 & 99.12 & $99.51 \pm 0.1331$ & 1.00 \\
\hline
\end{tabular}

*Replicated 3 times. RBS: Rabeprazole sodium, LEVO: Levosulpiride, SD: Standard deviation

Table 8: Specificity study for the synthetic mixture (LEVO: RBS=15:4)

\begin{tabular}{|c|c|c|c|c|c|c|c|}
\hline \multirow[t]{2}{*}{ Mix } & \multirow{2}{*}{$\begin{array}{l}\text { Concentrated } \\
(\mu \mathrm{g} / \mathrm{ml}) \\
\text { LEVO: RBS }\end{array}$} & \multirow[t]{2}{*}{$\lambda_{\max }(\mathrm{nm})$} & \multicolumn{2}{|c|}{ Before addition of excipients } & \multicolumn{2}{|c|}{ After addition of excipients } & \multirow[t]{2}{*}{$\%$ Interference } \\
\hline & & & Absorbance & Concentrated $(\mu \mathrm{g} / \mathrm{ml})$ & Absorbance & Concentrated $(\mu \mathrm{g} / \mathrm{ml})$ & \\
\hline \multirow[t]{2}{*}{1} & $30: 8$ & 255 & 0.5946 & 29.19 & 0.5935 & 29.06 & -0.445 \\
\hline & & 291.8 & 0.7019 & 7.41 & 0.7123 & 7.43 & 0.269 \\
\hline \multirow[t]{2}{*}{2} & $45: 12$ & 255 & 0.7611 & 44.1 & 0.7632 & 44.3 & 0.453 \\
\hline & & 291.8 & 0.9251 & 11.5 & 0.9239 & 11.3 & -1.739 \\
\hline 3 & $60: 16$ & 255 & 0.9020 & 59.3 & 0.9053 & 59.5 & 0.337 \\
\hline \multirow[t]{2}{*}{4} & $75: 20$ & 255 & 1.0445 & 74.2 & 1.0491 & 74.5 & 0.404 \\
\hline & & 291.8 & 1.3025 & 19.4 & 1.2785 & 19.6 & 1.03 \\
\hline \multirow[t]{2}{*}{5} & $90: 24$ & 255 & 1.1656 & 88.89 & 1.1695 & 89.2 & 0.348 \\
\hline & & 291.8 & 1.5092 & 23.78 & 1.5391 & 23.8 & 0.0841 \\
\hline \multirow[t]{2}{*}{6} & $105: 28$ & 255 & 1.3377 & 104.2 & 1.3564 & 104.5 & 0.287 \\
\hline & & 291.8 & 1.7069 & 27.6 & 1.6992 & 27.7 & 0.362 \\
\hline \multirow[t]{2}{*}{7} & $120: 32$ & 255 & 1.5162 & 119.2 & 1.5234 & 119.3 & 0.083 \\
\hline & & 291.8 & 1.9479 & 31.7 & 1.9325 & 31.4 & -0.946 \\
\hline Mean & RBS & & & & & & 0.145 \\
\hline
\end{tabular}

RBS: Rabeprazole sodium, LEVO: Levosulpiride

Table 9: Assay of rabeprazole and LEVO

\begin{tabular}{|c|c|c|c|c|c|c|}
\hline \multirow[t]{2}{*}{ Formulation } & \multicolumn{2}{|c|}{ Label claim (milligrams) } & \multicolumn{2}{|c|}{$\begin{array}{l}\text { Amount } \\
\text { found (milligrams) }\end{array}$} & \multicolumn{2}{|c|}{ Percentage assay $\pm S D(n=3)$} \\
\hline & RBS & LEVO & RBS & LEVO & RBS & LEVO \\
\hline Synthetic mixture & 20 & 75 & 19.76 & 74.4 & $98.25 \pm 0.2102$ & $99.2 \pm 0.4031$ \\
\hline Rabikind plus & 20 & 75 & 19.76 & 74.66 & $98.69 \pm 0.1934$ & $99.50 \pm 0.3093$ \\
\hline
\end{tabular}

RBS: Rabeprazole sodium, LEVO: Levosulpiride, SD: Standard deviation

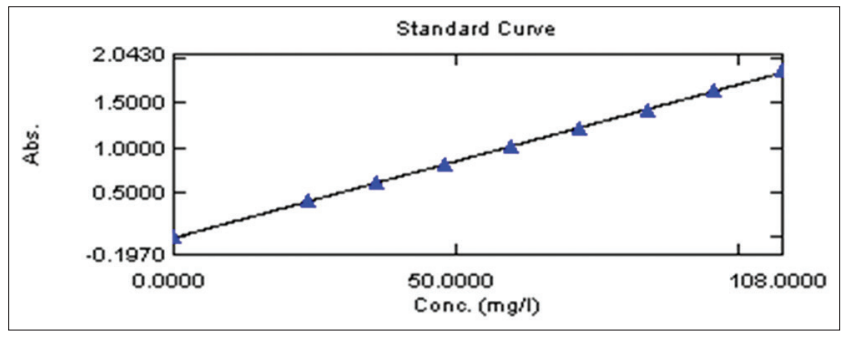

Fig. 11: Calibration curve for synthetic mixture at $291.8 \mathrm{~nm}$

The developed method was evaluated successfully for the content determination of marketed formulation of a combination of LEVO (75 mg) and RBS (20 mg) in capsule dosage form as well self-made synthetic mixture. It can also be used for any other solid dosage form for the same combination.

\section{REFERENCES}

1. O'Neil MJ. The Merck Index: An Encyclopedia of Chemicals, Drugs and Biologicals. 14 ${ }^{\text {th }}$ ed. Whitehouse Station, NJ: Merck Research Laboratories; 2011. p. 1041-3.

2. Rang HP, Dale MM, Ritter JM, Flower RJ. Rang and Dale's
Pharmacology. $6^{\text {th }}$ ed. Edinburgh, New York: Churchill Livingstone, Elsevier Science Ltd.; 2007.

3. Brunton LL, Parker KL. Goodman and Gilman's Manual of Pharmacology and Therapeutics. $11^{\text {th }}$ ed. New Delhi: The Mc Graw Hill Companies Inc.; 2005.

4. Ministry of Health and Family Welfare. Indian Pharmacopoeia. Vol. 3. Ghaziabad: Government of India, Ministry of Health and Family Welfare, The Indian Pharmacopoeia Commission; 2007. p. 1034-5.

5. Manjunath S, Chouhan V, Sandeep S. Spectrophotometric estimation of levosulpiride in bulk drug and formulations. Int J Pharm Pharm Sci 2011;3(2):135-7

6. Battu R, Prasanna A. Development and validation of RP-HPLC for the rabeprazole sodium in pharmaceutical formulations and human plasma. Asian J Res Chem 2009;2(1):49-51.

7. Surve S, Patwari A, Patel J, Rathod I, Chhabria M. HPTLC and HPLC method development and validation for simultaneous estimation of rabeprazole sodium and levosulpiride in bulk and its pharmaceutical dosage form. Int J Pharm Pharm Sci 2013;5(3):65-9.

8. Pattanayak P, Sharma R, Chaturvedi SC. Simultaneous spectrophotometric estimation of rabeprazole sodium and itopride $\mathrm{HCl}$. Anal Lett 2007;40(12):2288-94.

9. Saravanan G, Padmaja M, Geethanjali J, Visagaperumal D. Stability indicating RP-HPLC method for estimation of rabeprazole sodium and mosapride citrate in bulk and formulation. Int J Pharm Pharm Sci 2014;6(11):265-9. 
10. Skoog DA, Holler FJ, Crouch SR. Introduction to UV Spectroscopy Principle of Instrumental Analysis. $7^{\text {th }}$ ed. Bostan, USA: Cenage Learnings; 2007. p. 301.

11. Beckett AH, Stenlake JB. UV-Visible Spectrophotometry: Practical Pharmaceutical Chemistry. $4^{\text {th }}$ ed., Vol. 2. New Delhi: C.B.S. Publishers; 2001. p. 285-97.

12. Nadia DE. Preparation of drug sample for analysis. Handbook of
Pharmaceutical Analysis. New York: Marcel Dekker Inc.; 2002. p. 80-3. 13. Michael ES, Ira SK. Analytical Method Development and Validation. New York: Marcel Dekker Inc.; 1997. p. 25-9.

14. Text on Validation of Analytical Procedure, Q2A in ICH Harmonized Triplicate Guidelines, October; 1994.

15. Validation of Analytical Procedure Methodology, ICH Harmonized Tripartite Guideline, Q2B; 1996. p. 1-8. 